Journal of Anatolian Environmental and Animal Sciences

(Anadolu Çevre ve Hayvancılık Bilimleri Dergisi)

DOI: https://doi.org/10.35229/jaes.637729

\title{
Morphometric Aspects and Growth Parameters of the Wedge Clam (Donax trunculus) of the Black Sea, Turkey
}

\section{Mehmet AYDIN* Evren TUNCA Nurten ESEN ERSOY}

Fatsa Faculty of Marine Science, Ordu University, 52400 Turkey

How to cite: Aydın M., Tunca, E. \& Esen Ersoy, N. (2020). Morphometric Aspects and Growth Parameters of the Wedge Clam (Donax trunculus) of the Black Sea, Turkey. J. Anatolian Env. and Anim. Sciences, 5(1), 11-18.

Atıf yapmak için: Aydın M., Tunca, E. \& Esen Ersoy, N. (2020). Karadeniz'deki (Türkiye) kum şırlanının (Donax trunculus Linnaeus, 1758) büyüme ve morfometrik parametreleri. Anadolu Çev. ve Hay. Dergisi, 5(1), 11-18.

(DD: https://orcid.org/0000-0003-1163-6461 (iD): https://orcid.org/0000-0002-2842-2411

(iD): https://orcid.org/0000-0002-2899-5682

*Corresponding author's: Mehmet AYDIN

Fatsa Faculty of Marine Science, Ordu University, 52400 Turkey

凶: maydin69@hotmail.com

Mobile telephone : $+90(542) 4356280$

Fax : +90 (452) 4235053
Abstract: Donax trunculus, known as wedge clam, is an Atlantic-Mediterranean bivalve colonizing in fine sand beaches of the upper subtidal zone. Aim of this study is to determine the biometric features of wedge clam in sandy beaches, where they live in high-density, and the relationships between these features. The samples were collected for between March 2014February 2015 from an unexploited population from Black Sea. A total of 11045 samples were collected during this study. The shell length, shell width, shell thickness and shell weight, total weight and meat weight were measured. SL changes between 4.5 and $35.5 \mathrm{~mm}$ with an average value of $18.6 \pm 8.5 \mathrm{~mm}$. Average TW of the total sampling group was $1.2 \pm 1.1 \mathrm{~g}(0.007-4.64)$. Relationships between SL and SWe, SWi and SWe, ST and SWe were found as SWe $=0.0001$ $\mathrm{SL}^{2.9659}\left(\mathrm{R}^{2}=0.98\right), \quad \mathrm{SWe}=0.0002 \mathrm{SWi}^{3.3938}\left(\mathrm{R}^{2}=0.97\right)$ and $\mathrm{SWe}=0.0072 \mathrm{ST}^{2.6968} \quad\left(\mathrm{R}^{2}=0.89\right)$, respectively. Average MW of wedge clam was calculated as $0.2 \pm 0.2 \mathrm{~g}(0.001-2.74)$. The relationships between growth parameters were detailed by cluster analyses (CA), correlation analyses and comparison analyses. Results of this study have an important contribution to the present knowledge on the morphometric aspects and the growth parameters of the wedge clam in the Black Sea.

Keywords: Donax trunculus, growth, morphometric, shell, length-weight relationships.

\section{Karadeniz'deki (Türkiye) kum şırlanının (Donax trunculus Linnaeus, 1758) büyüme ve morfometrik parametreleri}

\author{
*Sorumlu yazar: \\ Mehmet AYDIN \\ Fatsa Deniz Bilimleri Fakültesi, Ordu \\ Üniversitesi, Ordu/Fatsa 52400, Turkey \\ $\triangle:$ maydin69@hotmail.com \\ Cep telefonu : $+90(542) 4356280$ \\ Faks : $\quad+90(452) 4235053$
}

Öz: Kum şılanı olarak bilinen, Donax trunculus, sı̆̆ kıyısal alanlarda kolinize olmuş AtlantikAkdeniz kökenli bir çift kabuklu türdür. Bu çalışmada, dalga hareketlerinin çok yüksek olduğu kumsal alanlarda yaşayan, kum şırlanı türünün biyometrik özellikleri ve bu özelliklerin birbiriyle ilişkileri belirlenmiştir. Çalışma, Güney Karadeniz Bölgesi kıyılarında hiç sömürülmemiş kum şırlanı popülasyonunda 12 ay (Mart 2014-Şubat 2015) boyunca periyodik örnekleme yapılarak gerçekleştirilmiştir. Çalışma süresi boyunca 11045 adet birey örneklenmiştir. Örneklenen bireylerde kabuk boyu, kabuk eni, kabuk kalınlığı, kabuk ağırlığı, toplam ağırlık ve et ağırlığı ölçümleri yapılmıştır. Kabuk boyları 4.5 ve $35.5 \mathrm{~mm}$ uzunlukları arasında değişmekte olup ortalama kabuk boyu $18.6 \pm 8.5 \mathrm{~mm}$ olarak hesaplanmıştır. Toplam ağırlık ortalaması ise $1.2 \pm$ $1.1 \mathrm{~g}(0.007-4.64)$ olarak belirlenmiş̧ir. KB-W, KE-W ve KK-W arasındaki ilişki sırasıyla $\mathrm{W}=0.0001 \mathrm{~KB}^{2.9659}\left(\mathrm{R}^{2}=0.98\right), \mathrm{W}=0.0002 \mathrm{KE}^{3.3938}\left(\mathrm{R}^{2}=0.97\right)$ ve $\mathrm{W}=0.0072 \mathrm{KK}^{2.6968}\left(\mathrm{R}^{2}=0.89\right)$ olarak tespit edilmiştir. Ortalama et ağırlığı ise $0.2 \pm 0.2 \mathrm{~g}(0.001-2.74)$ olarak belirlenmiştir. Yapılan bu çalıșma ile kum șırlanının Karadeniz Bölgesi'ndeki popülasyonunun büyüme parametreleri ve morfometrik özelliklerinin belirlenmesi açısından önemli katkılar sağlamıştır.

Anahtar kelimeler: Donax trunculus, büyüme, morfometri, kabuk, boy-ağırlık ilișkisi. 


\section{INTRODUCTION}

Species Donax trunculus Linnaeus, 1758 is widely distributed from Senegal, the north Atlantic Ocean coasts of France (Deval, 2009; Çolakoğlu, 2011) to the Black Sea and the Mediterranean Sea (Bayed \& Guillou, 1985; Çokaloğlu, 2014). Özden et al., (2009) reported that it is a commercially important species that is found abundantly in the northern Sea of Marmara. It is known that, the densest populations are formed in sand and tidal zones, especially in high-energetic seas (Gaspar et al., 1999). It feeds on organic material, specially by filtering phytoplankton (Mouëza \& Chessel, 1976). This species inhabits depths of $0-2 \mathrm{~m}$ in the Mediterranean Sea and 0-6 m in the Atlantic, generally forming stock in depths of 0-3 m (Gaspar et al., 2002a). There are stocks of $D$. trunculus in the coast of Turkey's Mediterranean Sea, Aegean Sea, Sea of Marmara and the Black Sea (Öztürk et al., 2014). Though it is not consumed as a food source in Turkey, it is extensively used for coastal fisheries as bait for pole or longlines. All the production is exported. There are legal legislations on the species in Turkey and it is illegal to harvest between $15^{\text {th }}$ April $-31^{\text {th }}$ August. Additionally, the minimum harvesting size is $2.5 \mathrm{~cm}$ (BSGM, 2016).

There are various studies conducted on wedge clam from the Atlantic Ocean (Bayed \& Guillou, 1985; Bayed, 1991, 1998; Guillou \& Bayed, 1991) and from the Mediterrranean Sea (Mouëza, 1972; Mouëza \& Chessel, 1976; Ansell \& Bodoy, 1979; Neuberger-Cywiak et al., 1990; Deval, 2009; Hafsaoui et al., 2016).

In this study, some biological and biometric features of $D$. trunculus were examined. There is limited information on the species from Turkey. This study will be a first on the species for the Turkish coast of the southern Black Sea.

\section{MATERIAL AND METHOD}

Sampling Area: Research was conducted between March 2014 - February 2015 in supralittoral sandy habitats between $0-1.5 \mathrm{~m}$ in depth, where the species is the densest, on the coast of Ordu, Black Sea (Figure 1).

Samples were collected with a hand dredge $(1.3 \mathrm{~cm}$ mesh size) and sieves (1-10 mm mesh size). Samples were preserved in seawater and were examined the same day. Shell length (SL), shell width (SWi) and shell thickness (ST) of $D$. trunculus were measured with a digital compass with $0.1 \mathrm{~mm}$ sensitivity. After these measurements, samples were dried on drying paper and total weight (TW) of the individual was measured with a Precisa sensitive scale with a sensitivity of $0.01 \mathrm{~g}$. Meat weight (MW) and shell weight (SWe) were also measured with the same scale for condition index. Length and weight relationship estimations were done by using Ricker (1975)'s exponential relationship models,

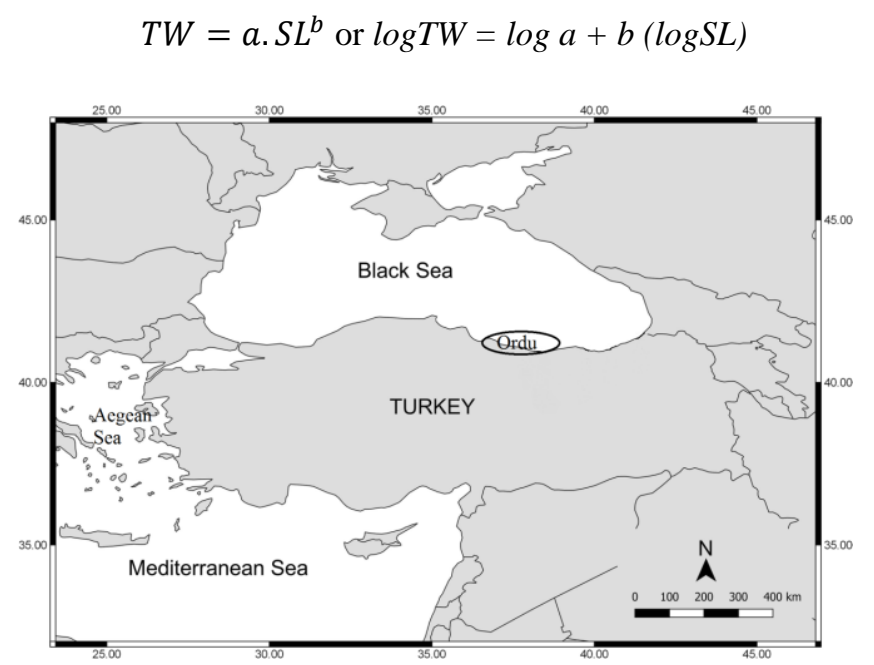

Figure 1. Sampling area.

Where a (intersection point) and $\mathrm{b}$ (slope) are regression constants, TW is total body weight (g) and SL is shell length $(\mathrm{mm})$. The "b" value was tested by t-test to check whether it was significantly different from 3 . When $b$ $=3$, it reflects an isometric growth, when it is $b \neq 3$ it reflects an allometric growth (positive $\mathrm{b}>3$ or negative $\mathrm{b}<3$ ) (Froese, 2006; Aydın \& Sözer, 2019).

Estimation of SL-SWi, SL-ST and ST- SWi relationships were done using linear relationship models,

$(\mathrm{SWi}=\mathrm{a}+\mathrm{b} . \mathrm{SL}, \mathrm{ST}=\mathrm{a}+\mathrm{b} . \mathrm{SL}, \mathrm{ST}=\mathrm{a}+\mathrm{b} . \mathrm{SWi})$

To estimate the growth rate, SL and TW were used with the following equations: SLn-1] x100,

Shell length increase percentage $=[(\mathrm{SLn}-\mathrm{SLn}-1) /$ TWn-1] x100

Weight increase percentage $=[(\mathrm{TWn}-\mathrm{TWn}-1) /$

D. trunculus condition index (CI) ratio was estimated using TW, MW and SWe (Çolakoğlu \& Tokaç, 2011),

\section{$\mathrm{CI}=\mathrm{MW} /(\mathrm{TW}-\mathrm{SWe}) \times 100$}

SPSS Statistical Package and MS Office-Excel software were used for data analyzes. Distribution of the data was checked, and monthly averages of the data were compared. Due to high sample numbers, KolmogorovSmirnov test was chosen amongst the distribution tests and found out that the data showed nonparametric distribution. Nonparametric tests were used to compare monthly averages. To determine if there were differences between months and seasons, Kruskal Wallis test was used, and Mann Whitney-U test was used to determine which months and seasons were different (Aydın et al., 2014). All these tests were conducted within $95 \%$ confidence level on SPSS v. 21 (IMB, USA). Correlation analysis were done to evaluate the relationships between parameters. Spearman correlation analysis was chosen because the data were nonparametric. Cluster analysis was used for evaluation of similarities 
among variables. Ward method was used with Euclidean Distance, and Z-score correction was also done for cluster analysis (Tunca et al., 2016).

\section{RESULTS}

Length and weight frequency distribution: In total 11045 individuals of $D$. trunculus were sampled and shell lengths ranged between 4.5 and $35.5 \mathrm{~mm}$. The length and weight frequencies of $D$. trunculus are given in Figure 2.

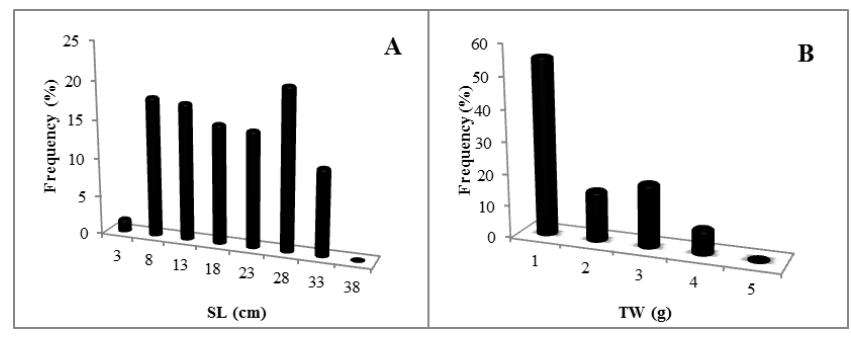

Figure 2. D. trunculus length frequency (A) weight frequency (B).

Monthly length frequency distribution: Monthly length frequencies of the samples are given in Figure 3.

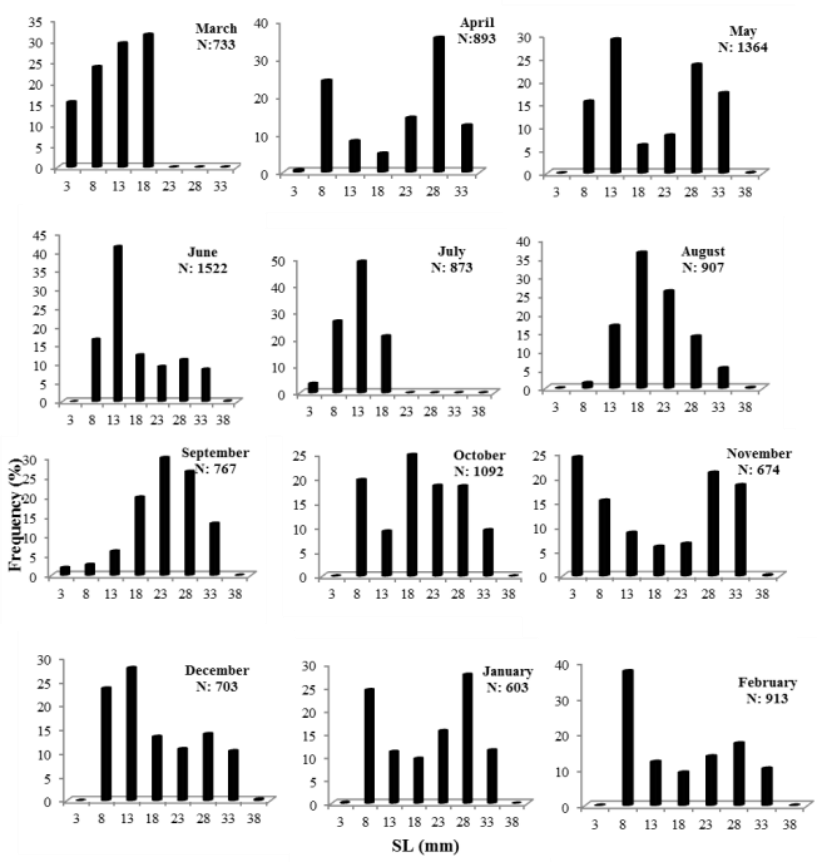

Figure 3. Monthly length frequencies.

Biometric data: The average shell length was calculated as $18.6 \pm 8.5 \mathrm{~mm}$ (min: 4.5 - $\max : 35.5$ ). The average total weight was $1.2 \pm 1.1 \mathrm{~g}(0.007-4.64)$. Biometric measurements of all the samples are given in Table 1.

Table1. D .trunculus biometric measurements.

\begin{tabular}{lcccccc}
\hline & SL $(\mathbf{m m})$ & $\mathbf{S W i}(\mathbf{m m})$ & $\mathbf{S T}(\mathbf{m m})$ & $\mathbf{T W}(\mathbf{g})$ & $\mathbf{M W}(\mathbf{g})$ & $\mathbf{S W}(\mathbf{g})$ \\
& $\mathbf{N}: \mathbf{1 1 0 4 5}$ & $\mathbf{N : 1 1 0 4 5}$ & $\mathbf{N}: \mathbf{1 1 0 4 5}$ & $\mathbf{N : 1 1 0 4 5}$ & $\mathbf{N : 8 0 9 2}$ & $\mathbf{N : 6 9 0 3}$ \\
\hline Mean & $18.6 \pm 8.5$ & $10.7 \pm 4.3$ & $5.5 \pm 2.5$ & $1.2 \pm 1.1$ & $0.2 \pm 0.2$ & $0.7 \pm 0.7$ \\
Minimum & 4.5 & 2.5 & 0.5 & 0.007 & 0.001 & 0.007 \\
Maximum & 35.5 & 20 & 11 & 4.64 & 2.74 & 2.95 \\
\hline
\end{tabular}

In this study, the relationship between SWi and TW showed positive allometry ( $b>3$ ), and negative allometry between ST and TW, and SL and TW (b<3) (Figure 4).
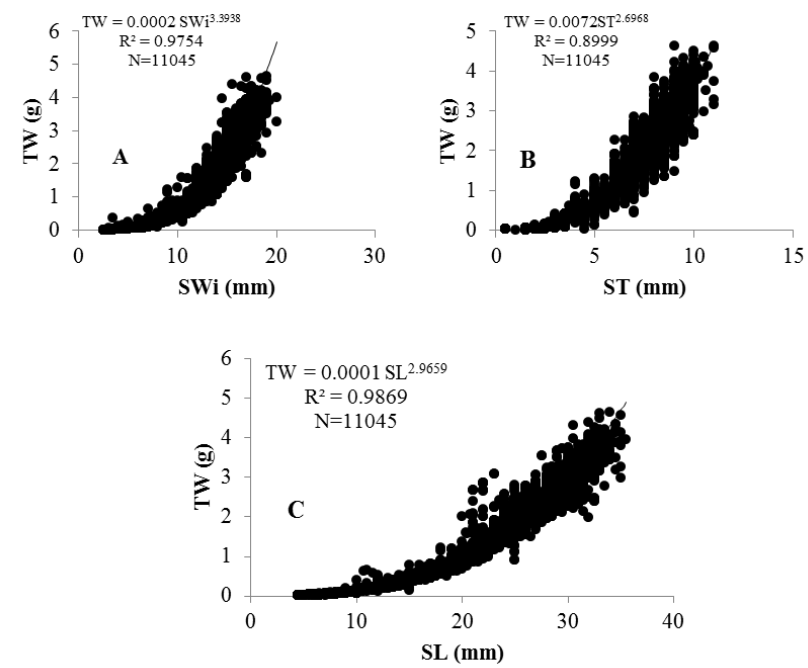

Figure 4. Relationships between shell width - total weight (A), shell thickness - total weight (B), shell length - total weight (C).

Linear relationships were identified between SL and SWi, SL and ST and SWi and ST for all the D. trunculus samples (Figure 5).

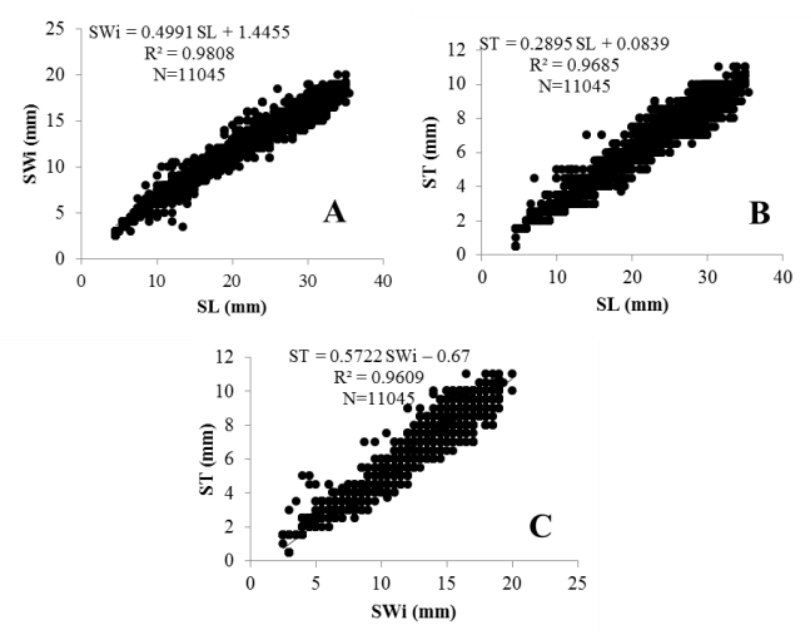

Figure 5. Relationships between shell length - shell width (A), shell length - shell thickness (B) shell width - shell thickness (C).

Linear relationships were identified between SW and MW and TW and MW. An exponential function was fitted for the relationship between SL and MW (Figure 6).

Growth Rate: The growth rate was estimated using SL and TW. The highest growth rate by weight was estimated for the 10-15 mm length group (326.3\%) and the lowest for the 35-40 mm length group (23.1\%). The highest growth by length was estimated for 5-10 mm length group $(63.1 \%)$ and the lowest was estimated for 30-35 mm length group $(13.0 \%)$ (Table 2). 


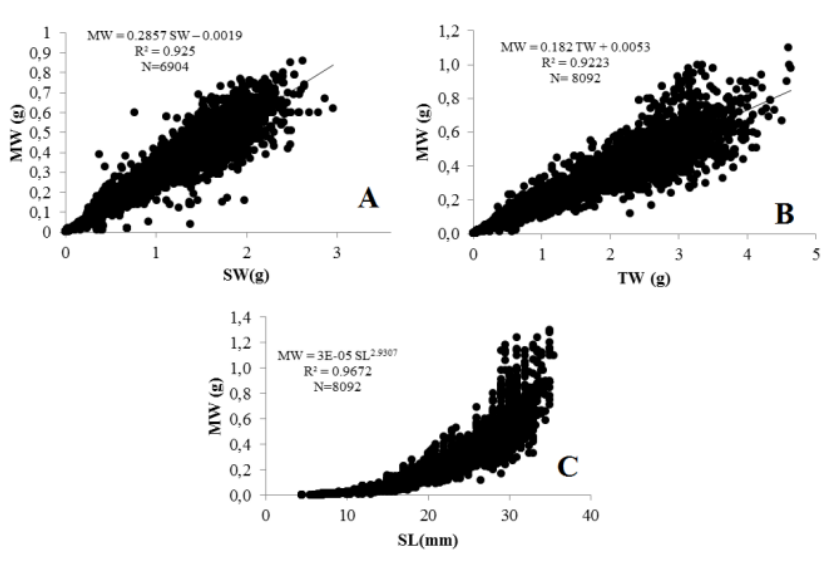

Figure 6. Relationships between shell weight - meat weight (A), total weight - meat weight (B), shell length - meat weight (C)
Table 2. Growth performance value of D. trunculus.

\begin{tabular}{lllllll}
\hline $\mathbf{S L}(\mathbf{m m})$ & $\mathbf{N}$ & $\%$ & Mean SL $(\mathbf{m m})$ & Mean TW $(\mathbf{g})$ & $\begin{array}{l}\text { Increasing in } \\
\text { length }(\%)\end{array}$ & $\begin{array}{l}\text { Increasing in } \\
\text { weight }(\%)\end{array}$ \\
\hline $0-5$ & 191 & 1.73 & $4.5 \pm 0.01$ & $0.02 \pm 0.001$ & - & - \\
$5-10$ & 2005 & 18.15 & $7.3 \pm 0.9$ & $0.05 \pm 0.02$ & $\mathbf{6 3 . 1}$ & 160.0 \\
$10-15$ & 1957 & 17.72 & $11.7 \pm 1.5$ & $0.2 \pm 0.1$ & 59.9 & $\mathbf{3 2 6 . 3}$ \\
$15-20$ & 1704 & 15.43 & $17.2 \pm 1.5$ & $0.6 \pm 0.2$ & 46.9 & 201.5 \\
$20-25$ & 1654 & 14.98 & $22.1 \pm 1.4$ & $1.3 \pm 0.3$ & 28.3 & 116.7 \\
$25-30$ & 2292 & 20.75 & $27.4 \pm 1.4$ & $2.3 \pm 0.4$ & 23.8 & 81.7 \\
$30-35$ & 1232 & 11.16 & $30.9 \pm 1.0$ & $3.1 \pm 0.3$ & $\mathbf{1 3 . 0}$ & 32.5 \\
$35-40$ & 10 & 0.08 & $35.1 \pm 0.2$ & $3.8 \pm 0.5$ & 13.4 & $\mathbf{2 3 . 1}$ \\
\hline Total & $\mathbf{1 1 0 4 5}$ & $\mathbf{1 0 0}$ & $\mathbf{1 8 . 6 2} \pm \mathbf{8 . 4 7}$ & $\mathbf{1 . 1 7} \pm \mathbf{1 . 1 2}$ & $\mathbf{3 5 . 5}$ & $\mathbf{1 3 4 . 5}$ \\
\hline & & & & & &
\end{tabular}

Condition Index: The condition index, that represents the fullness of the soft tissue in the shell cavity of a bivalve mollusk, is expressed as the rate of occupancy using the method of condition index by weight, was calculated by examining 6929 individuals. The highest average value was estimated for May $(121.3 \pm 18.2)$ and the lowest was August (42.8 $\underline{1}$ 19.82) (Table 3).

Statistical Analyzes: The monthly average values of the parameters are given in Table 3 .

Table 3. Monthly comparison of size parameters and condition index $(\mathrm{p}<0.05)$

\begin{tabular}{|c|c|c|c|c|c|c|c|c|c|c|c|c|c|}
\hline & & $\begin{array}{l}\text { Mar. } \\
\text { (A) }\end{array}$ & $\begin{array}{l}\text { Ap. } \\
\text { (B) }\end{array}$ & $\begin{array}{l}\text { May } \\
\text { (C) }\end{array}$ & $\begin{array}{l}\text { Jun. } \\
\text { (D) }\end{array}$ & $\begin{array}{l}\text { Jul. } \\
\text { (E) }\end{array}$ & $\begin{array}{l}\text { Aug. } \\
\text { (F) }\end{array}$ & $\begin{array}{l}\text { Sep. } \\
\text { (G) }\end{array}$ & $\begin{array}{l}\text { Oct. } \\
\text { (H) }\end{array}$ & $\begin{array}{l}\begin{array}{l}\text { Nov. } \\
\text { (I) }\end{array} \\
\end{array}$ & $\begin{array}{l}\text { Dec. } \\
(\mathrm{J})\end{array}$ & $\begin{array}{l}\text { Jan. } \\
(\mathbf{K})\end{array}$ & $\begin{array}{l}\text { Feb. } \\
\text { (L) }\end{array}$ \\
\hline \multirow{5}{*}{ 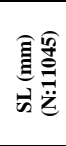 } & Mean & $\begin{array}{l}18.79 \\
\end{array}$ & 20.3 & $\begin{array}{l}19.18 \\
\end{array}$ & 16.04 & 19.55 & 19.87 & 19.05 & 22.47 & 17.26 & 16.55 & $\begin{array}{l}19.27 \\
\end{array}$ & 16.63 \\
\hline & Min. & 4.5 & 4.5 & 8 & 8 & 6.5 & 6.5 & 5.5 & 4.5 & 4.5 & 5 & 4.5 & 6.5 \\
\hline & Max. & 34 & 34 & 35.5 & 35 & 35 & 35 & 33.5 & 34.5 & 35 & 35 & 34 & 34 \\
\hline & S.D. & 0.34 & 0.30 & 0.24 & 0.2 & 0.23 & 0.18 & 0.23 & 0.23 & 0.42 & 0.33 & 0.37 & 0.3 \\
\hline & Dif. & $\mathrm{A}^{\mathrm{e}, \mathrm{f}, \mathrm{g}, \mathrm{k}}$ & $\mathrm{B}^{\mathrm{c}}$ & $\mathrm{C}^{\mathrm{b}, \mathrm{e}, \mathrm{g}, \mathrm{k}}$ & $\mathrm{D}^{\mathrm{i}, \mathrm{j}}$ & $E^{a, c, f, g, g, k}$ & $\mathrm{~F}^{\mathrm{a}, \mathrm{e}, \mathrm{k}}$ & $\mathrm{G}^{\mathrm{a}, \mathrm{c}, \mathrm{e}, \mathrm{k}}$ & $\mathrm{H}$ & $\mathrm{I}^{\mathrm{d} \mathrm{j}, \mathrm{I}, 1}$ & $\mathrm{~J}^{\mathrm{d}, \mathrm{d}, \mathrm{I}}$ & $\mathrm{K}^{\mathrm{a}, \mathrm{a}, \mathrm{e}, \mathrm{f}, \mathrm{g}}$ & $\mathrm{L}^{\mathrm{i}, \mathrm{j}}$ \\
\hline \multirow{5}{*}{ 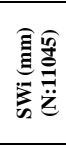 } & Mean & 10.80 & 11.52 & 11.07 & 9.63 & 11.27 & 11.45 & 10.96 & 12.76 & 9.87 & 9.56 & 10.91 & 9.54 \\
\hline & Min. & 2.5 & 2.5 & 5.5 & 5.5 & 4.2 & 4. & 3.5 & 3 & 3 & 3 & 2.5 & 4 \\
\hline & Max. & 19 & 20 & 19 & 18.5 & 19 & 18.5 & 18.5 & 18.6 & 20 & 19.3 & 17.5 & 19 \\
\hline & S.D. & 0.17 & 0.15 & 0.12 & 0.1 & 0.12 & 0.09 & 0.11 & 0.12 & 0.22 & 0.17 & 0.19 & 0.16 \\
\hline & Dif. & $\mathrm{A}^{\mathrm{e}, \mathrm{f}, \mathrm{g}, \mathrm{k}}$ & $\mathrm{B}^{\mathrm{c}}$ & $\mathrm{C}^{\mathrm{b}, \mathrm{e}, \mathrm{f}, \mathrm{g}}$ & $\mathrm{D}^{\mathrm{i}, \mathrm{j}}$ & $\mathrm{E}^{\mathrm{a}, \mathrm{c}, \mathrm{f}, \mathrm{g}, \mathrm{k}, \mathrm{k}}$ & $\mathrm{F}^{\mathrm{a}, \mathrm{c}, \mathrm{c}, \mathrm{k}}$ & $\mathrm{G}^{\mathrm{a}, \mathrm{c}, \mathrm{e}, \mathrm{k}}$ & $\mathrm{H}$ & $I^{\mathrm{d}, \mathrm{j}, 1}$ & $\mathrm{~J}^{\mathrm{d}, \mathrm{i}, 1}$ & $\mathrm{~K}^{\mathrm{a}, \mathrm{e}, \mathrm{f}, \mathrm{g}}$ & $\mathrm{L}^{\mathrm{i}, \mathrm{j}}$ \\
\hline \multirow{5}{*}{ 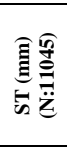 } & Mean & 5.6 & 6 & 5.7 & 4.8 & 5.7 & 5.7 & 5.52 & 6.62 & 4.84 & 4.83 & 5.66 & 5 \\
\hline & Min. & 1.5 & 1.5 & 2.5 & 2.5 & 2 & 2 & 1.5 & 1.5 & 0.5 & 1.5 & 1 & 2 \\
\hline & Max. & 11 & 10 & 10 & 10.5 & 11 & 11 & 10 & 10.2 & 11 & 10.5 & 10 & 10 \\
\hline & S.D. & 0.09 & 0.08 & 0.07 & 0.06 & 0.07 & 0.57 & 0.07 & 0.07 & 0.14 & 0.1 & 0.11 & 0.09 \\
\hline & Dif. & $\mathrm{A}^{\mathrm{e}, \mathrm{f}, \mathrm{g}, \mathrm{k}}$ & $\mathrm{B}^{\mathrm{c}, \mathrm{k}}$ & $C^{b, e, f, g}$ & $\mathrm{D}^{\mathrm{i}, \mathrm{j}, \mathrm{l}}$ & $\mathrm{E}^{\mathrm{a}, \mathrm{c}, \mathrm{f}, \mathrm{g}, \mathrm{k}, \mathrm{k}}$ & $\mathrm{F}^{\mathrm{a}, \mathrm{c}, \mathrm{e}, \mathrm{k}}$ & $\mathrm{G}^{\mathrm{a}, \mathrm{c}, \mathrm{e}, \mathrm{k}}$ & $\mathrm{H}$ & $\mathrm{I}^{\mathrm{d}, \mathrm{j}}$ & $\mathrm{J}^{\mathrm{d}, \mathrm{i}, 1}$ & $\mathrm{~K}^{\mathrm{a}, \mathrm{b}, \mathrm{e}, \mathrm{f}, \mathrm{g}}$ & $\mathrm{L}^{\mathrm{d}, \mathrm{j}}$ \\
\hline \multirow{5}{*}{ 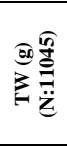 } & Mean & 1.35 & 1.53 & 1.35 & 0.79 & 1.14 & 1.05 & 1.12 & 1.5 & 1.23 & 0.93 & 1.27 & 1 \\
\hline & Min. & 0.014 & 0.014 & 0.054 & 0.054 & 0.061 & 0.027 & 0.022 & 0.01 & 0.019 & 0.019 & 0.007 & 0.02 \\
\hline & Max. & 4.64 & 4 & 4.08 & 4.34 & 4.62 & 4.58 & 3.95 & 4.22 & 4.28 & 3.9 & 3.77 & 4.4 \\
\hline & S.D. & 0.04 & 0.04 & 0.04 & 0.03 & 0.03 & 0.03 & 0.03 & 0.03 & 0.05 & 0.04 & 0.05 & 0.04 \\
\hline & Dif. & $\mathrm{A}^{\mathrm{e}, \mathrm{f}, \mathrm{g}, \mathrm{k}}$ & $\mathrm{B}^{\mathrm{c}}$ & $C^{b, f, g}$ & $\mathrm{D}$ & $\mathrm{E}^{\mathrm{a}, \mathrm{f}, \mathrm{g}, \mathrm{k}}$ & $F^{a, c, e, k}$ & $\mathrm{G}^{\mathrm{a}, \mathrm{c}, \mathrm{e}, \mathrm{k}}$ & $\mathrm{H}$ & $\mathrm{I}^{\mathrm{j}, 1}$ & $\mathrm{~J}^{\mathrm{j}, 1}$ & $\mathrm{~K}^{\mathrm{a}, \mathrm{e}, \mathrm{f}, \mathrm{g}}$ & $\mathrm{L}^{\mathrm{i}, \mathrm{j}}$ \\
\hline \multirow{4}{*}{ こ } & Mean & 59.5 & 61.9 & 121.3 & 73.8 & 56.2 & 42.8 & 55.4 & 46.1 & 52.3 & 51.2 & 44.9 & 53.8 \\
\hline & Min. & 16.7 & 12.5 & 15.6 & 17.5 & 16.8 & 15.4 & 14.2 & 8.7 & 16.3 & 16.3 & 13 & 11.5 \\
\hline & Max. & 209.1 & 191.7 & 273.9 & 175.6 & 224.0 & 172.7 & 120.3 & 206.1 & 221.4 & 192.3 & 133.3 & 260.0 \\
\hline & $\begin{array}{l}\text { S.D. } \\
\text { Dif. }\end{array}$ & $\begin{array}{l}20.94 \\
A^{b}\end{array}$ & $\begin{array}{l}23.33 \\
\mathrm{~B}^{\mathrm{a}}\end{array}$ & $\begin{array}{l}18.2 \\
C\end{array}$ & $\begin{array}{l}46.29 \\
\text { D }\end{array}$ & $\begin{array}{l}22.56 \\
E^{\mathrm{i}, j, 1}\end{array}$ & $\begin{array}{l}19.82 \\
F\end{array}$ & $\begin{array}{l}24.58 \\
\mathrm{G}^{\mathrm{i}, \mathrm{j}}\end{array}$ & $\begin{array}{l}17.45 \\
\mathrm{H}^{\mathrm{k}}\end{array}$ & $\begin{array}{l}19.66 \\
\mathrm{I}^{\mathrm{e}, \mathrm{g}, \mathrm{j}, 1}\end{array}$ & $\begin{array}{l}16.77 \\
\text { Je.g.i. }\end{array}$ & $\begin{array}{l}19.28 \\
\mathrm{~K}^{\mathrm{h}}\end{array}$ & $\begin{array}{l}24.80 \\
\text { e.i.j.j. }\end{array}$ \\
\hline
\end{tabular}

Explanations: A capital and a superscript letters denote comparisons between two months. There is no statistical difference at the level of $95 \%$ between a capital letter and each superscript letter.

Given the morphometric data, statistically significant largest $D$. trunculus values were in October (Table 3). April and May followed October, and the lowest values were in June. In case of condition index, it was different and the highest statistically significance value of condition index was May, while the lowest was August. Seasonal comparison of SL, SWi and ST were as Spring = Autumn $>$ Summer $>$ Winter, and for TW it was as Spring $>$ Autumn > Winter > Summer. Unlike the other parameters, TW was found significant and a statistical difference was found between Spring and Autumn.

In general, high correlation was found for all months and in the total (Table 4). The highest value was found as 1.00 (a hundred percent) in May between TW and SWe. The lowest correlation value was 0.749 , between ST and SWe in June. June is also notable for SWe showing the lowest correlation with other parameters. Another low correlation was observed between MW with other parameters in November. Given the annual comparison, though correlation between MW and SWe values were strong when compared to the correlation between the other parameters, it was found to be relatively weaker.

In case of cluster analyses; there were two different clusters, SL, SWi and ST measurements formed a cluster and BW, SW and MW formed the other (Figure 7). The strongest relation was observed between SL and SWi with 10.29, value of the closest Euclid distance (Table 5). Relatively the furthest distance to other parameters was observed for MW. These results also show parallelism to the annual correlation values. 
Table 4. Correlation between monthly and annual parameters.

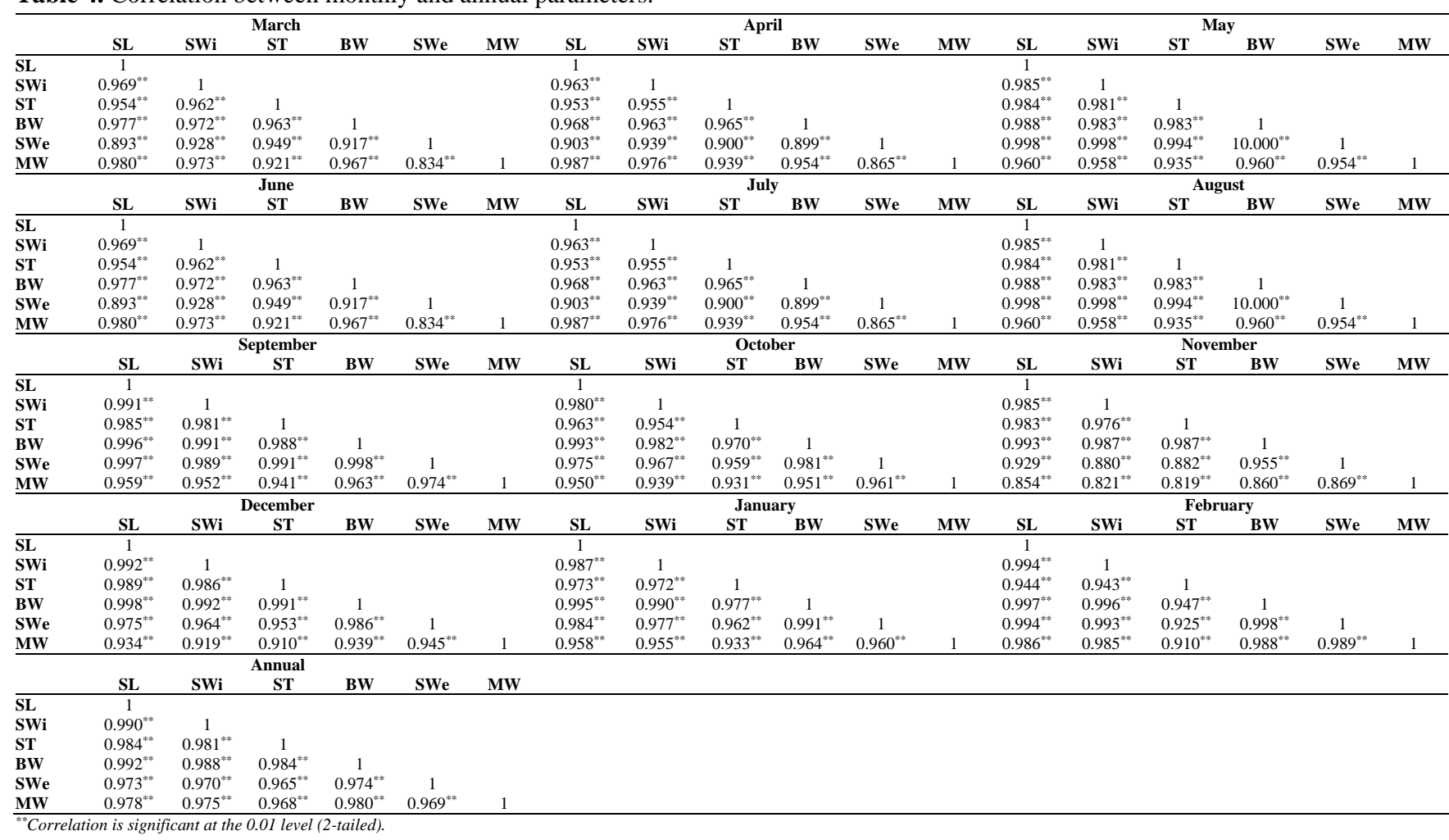

Table 5. Cluster analyses matrix of measured parameters.

\begin{tabular}{lcccccc}
\hline & $\begin{array}{c}\text { Shell length } \\
(\mathbf{S L})\end{array}$ & $\begin{array}{c}\text { Shell width } \\
(\mathbf{S W i})\end{array}$ & $\begin{array}{c}\text { Shell thickness } \\
(\mathbf{S T})\end{array}$ & $\begin{array}{c}\text { Total weight } \\
(\mathbf{T W})\end{array}$ & $\begin{array}{c}\text { Shell weight } \\
(\mathbf{S W})\end{array}$ & $\begin{array}{c}\text { Meat weight } \\
(\mathbf{M W})\end{array}$ \\
\hline Shell length & 0.000 & & & & & \\
Shell width & 10.288 & 0.000 & & & & \\
Shell thickness & 13.629 & 16.125 & 0.000 & & & \\
Total weight & 25.084 & 29.429 & 24.672 & 0.000 & & \\
Shell weight & 31.969 & 35.074 & 31.556 & 22.098 & 0.000 & \\
Meat weight & 33.582 & 36.473 & 33.598 & 25.838 & 30.842 & 0.000 \\
\hline
\end{tabular}

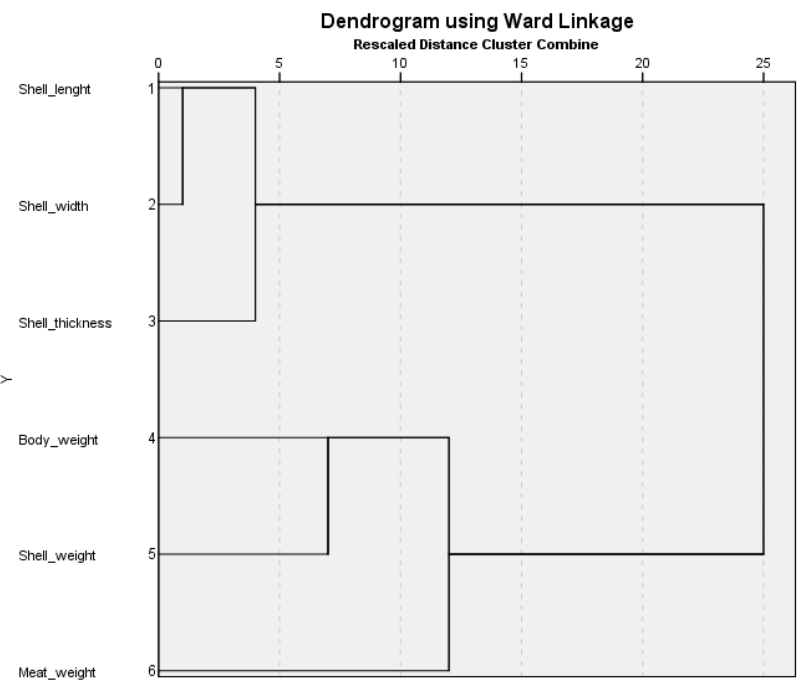

Figure 7. Cluster analyses dendrogram of the measured data.

\section{DISCUSSION}

Total of 11045 individuals of D. trunculus were measured. In other studies, conducted on D. trunculus, number of examined individuals were 995 individuals from
Black Sea by Y1lmazer (2005), and from Sea of Marmara; 4624 individuals by Çolakoğlu (2011), 3428 individuals by Çolakoğlu and Tokaç (2011), 2098 individuals by Deval (2009) and 2558 individuals by Çolakoğlu (2014). Among the number of individuals examined in Turkey. This study is the highest and study by Deval (2009) second.

The shell length of $D$. trunculus individuals were found between $4.5-35.5 \mathrm{~mm}$ in this study, where it was conducted on sandy habitats of the coastal areas of Ordu in Black Sea. The average shell length was estimated as $18.6 \pm 8.5 \mathrm{~mm}$. According to the study by Y1lmazer (2005) conducted at Şile coasts of west Black Sea, the smallest individual was measured to be $11.6 \mathrm{~mm}$ and the largest $43.1 \mathrm{~mm}$. Çolakoğlu \& Tokaç (2011) estimated the average length $28.7 \mathrm{~mm}$, and the length range as $13-42 \mathrm{~mm}$ for Sea of Marmara. Another study, from northern Sea of Marmara by Deval (2009) found the length range was between 3-44.8 mm $\left(\mathrm{L}_{\text {average }}=24.7 \mathrm{~mm}\right)$. Çolakoğlu (2014) reported the length range to be between $10-42 \mathrm{~mm}$. The other studies from other seas reported the highest estimated length $\left(\mathrm{L}_{\infty}\right)$ as $52.84 \mathrm{~mm}$ by Mazé \& Laborda (1988) from Atlantic Ocean coasts, and the lowest estimated length $\left(\mathrm{L}_{\infty}\right)$ as $35.9 \mathrm{~mm}$ by Bodoy (1982) from the Mediterranean Sea. In another study from the Spanish coasts the length range was found between 5-45 mm (Huz et al., 2002), and in the studies from the coasts of southern Portugual the length range was found between $8.9-44.3 \mathrm{~mm}\left(\mathrm{~L}_{\text {average }}=26.5 \mathrm{~mm}\right)$ and 16-44 $\mathrm{mm}\left(\mathrm{L}_{\text {average }}=27.3 \mathrm{~mm}\right)($ Gaspar et al. 2002a), and the maximum length as $31 \mathrm{~mm}$ (Gaspar et al., 2003). In a study conducted in the southern Adriatic coasts of 
Italy, the maximum length was reported as $37 \mathrm{~mm}$ (Zeichen et al., 2002). The maximum length values were found in this study therefore, it can be said that, they are similar, when compared with " $L_{\infty}$ " values reported from Atlantic Ocean and Mediterranean Sea. Though when compared with studies conducted in Sea of Marmara, the individuals from Sea of Marmara seem to be larger than the population from the Black Sea. In both studies from Sea of Marmara, the average length and maximum length were reported to be larger. This difference is due to using different sampling gears. In this study, due to a different sampling gear, smaller individuals were sampled which resulted in smaller average length. Especially in Turkey, the study conducted in Sea of Marmara indicated that individuals in Sea of Marmara are larger from the individuals in Black Sea. It can be said that the main reasons for this difference are environmental variables such as salinity, temperature, oxygen and the difference in sampling depth and gear.

The highest growth rate in length was found in 5$10 \mathrm{~mm}$ length group. Neuberger-Cywiak et al., (1990) found similar results and reported the highest growth rate at the first 2.5 months, and Hafsaoui et al., (2016) reported the highest growth rate within the first year. Individuals within the length group $25-30 \mathrm{~mm}$ constitutes $20.75 \%$ of overall samples. The ratio of the individual identified as juveniles $(<15 \mathrm{~mm})$ corresponds to $40.9 \%$ of the overall sample. The length at maturity was identified from Algeria by Moueza \& Frenkiel-Renault (1973) as $16 \mathrm{~mm}$, from Spain by Tirado \& Salas (1998) as 13.3, from Portugal by Gaspar et al., (1999) as $13 \mathrm{~mm}$, from Italy by Zeichen et al., (2002) as $18 \mathrm{~mm}$ and from Sile Black Sea coast of Istanbul by Yilmazer (2005) as $18.9 \mathrm{~mm}$. The length group within this study, which had the highest number of individuals $(25-30 \mathrm{~mm})$, was found to be higher from the reported length at maturity from other studies. Çolakoğlu (2011) reported the weight range between $0.26-17.22 \mathrm{~g}$ and the average weight as $3.04 \mathrm{~g}$. In this study, the average weight was found to be $1.2 \pm 1.1 \mathrm{~g}(0.007-4.64 \mathrm{~g})$. There is a notable difference between Çolakoğlu (2011) and this study. This difference is due to difference in sampling gears. Since metal sieves were used in this study, the number of small sized individual was very high. A $33.5 \%$ of the total sampling of this study (3684 individuals) is lower than the smallest individual reported by Çolakoğlu (2011) (0.26 g).

Additionally, Çolakoğlu (2011) reported the relationships between $\mathrm{SL}$ and TW as TW $=0.153 \mathrm{SL}^{2.73}$ $\left(R^{2}=0.95\right)$, between ST and TW as TW $=0.667 \mathrm{ST}^{2.68}\left(\mathrm{R}^{2}=\right.$ $0.93)$, and between $\mathrm{SWi}$ and TW as TW=3.12 $\mathrm{SWi}^{2.30}\left(\mathrm{R}^{2}=\right.$ $0.86)$. In this study the relationships were estimated between SL and TW as TW=0.0001 $\mathrm{SL}^{2.96}\left(\mathrm{R}^{2}=0.9659\right)$, between $\mathrm{ST}$ and TW as TW $=0.0072 \mathrm{ST}^{2.6968}\left(\mathrm{R}^{2}=0.8999\right)$, and between SWi and TW as TW $=0.0002 \mathrm{SWi}^{3.3938}\left(\mathrm{R}^{2}=\right.$
0.9754). In both studies, except for the relationships between SWi-TW, all showed negative allometry.

The " $b$ " value of the relationship between SL and MW was estimated as $2.9659(b<3)$. The other studies from various areas on this species also reported the " $b$ " value $\mathrm{b}<3$ and growth as negative allometry (Guillou, 1980; Bayed, 1990; Mazé \& Laborda, 1990; Deval, 2009; Çolakoğlu, 2011; Çolakoğlu \& Tokaç, 2011; Çolakoğlu, 2014). The studies reported as the "b" value changing between 2.5-3.5 and value being smaller than 3 indicate negative allometry (Ricker, 1975; Çolakoğlu, 2011).

In this study, a strong linear relation was observed between SL and SWi $\left(\mathrm{SWi}=0.4991 \mathrm{SL}+1.4455, \mathrm{R}^{2}=\right.$ 0.98). Çolakoğlu (2011) reported the relationship between SWi and $\mathrm{SL}$ as $\mathrm{SWi}=0.556 \mathrm{SL}+0.0962\left(\mathrm{R}^{2}=0.87\right)$. The study conducted at the coasts of Portugal reported the relationship between length and width as $\log \mathrm{SWi}=$ 0.067+0.888 Log SL $\left(R^{2}=0.934\right)(G a s p a r$ et al. 2002b). When all these studies are compared, the strongest relationship between SL and SWi was from this study. It is known that the difference in regression constants can be the result of difference in environmental factors effecting the species growth (Parsons et al., 1990).

Çolakoğlu (2011) reported an exponential relationship between SWi and SL $\left(\mathrm{SWi}=0.658 \mathrm{SL}^{0.965}\left(\mathrm{R}^{2}\right.\right.$ $=0.918)$ ). In this study, the regression coefficient was found as $R^{2}=0.98$ and can be said that the linear relationship between SWi and SL is stronger.

Çolakoğlu (2011) reported the condition index of D. trunculus the highest in April (95.6) in the Marmara Sea, and the lowest in July (53.9). However, Deval (2009) study from the northern Sea of Marmara reported that the condition index starts to increase in February, reaching its highest in May and lowest in August. In this study, the estimated condition index of $D$. trunculus was maximum in May (121.3 \pm 18.2$)$, and minimum in August (42.8 \pm 19.82). The results showed similarity with Deval (2009) study. Since the reproduction season showed parallelism with the period of maximum condition index value, it can be said that the reproduction season is between May and August. The studies conducted in other areas also reported that the reproduction season is between May and August (Bayed, 1990; Gaspar et al., 1999; Zeichen et al., 2002). Similarly, the study conducted on Şile coasts of Black Sea reported the reproduction season between May and August (Yilmazer, 2005). Studies from other areas reported that the reproduction period is in spring and summer seasons (Zeichen et al., 2002; Deval, 2009), and the low growth period is the result of low condition values of the reproduction period.

Results of this study have an important contribution to the present knowledge on the morphometric aspects and the growth parameters of the wedge clam in the 
southern Black Sea region. Additionally, this study shows importance as being the first study conducted from the southern Black Sea.

\section{ACKNOWLEDGEMENTS}

This research was supported by the Ordu University Scientific Research Coordination Unit with the project No. TF-1606

\section{REFERENCES}

Ansell, A.D. \& Bodoy, A. (1979). Comparison of events in the seasonal cycle for Donax vittatus and D. trunculus. In: Cyclic phenomena in marine plants and animals, Proceedings of the 13th European Marine Biology Symposium. Naylor, E, Hartno, R.G. (Eds). Pergamon Press, Oxford, New York, 191-198.

Aydın, M., Karadurmuş, U. \& Tunca, E. (2014). Biological characteristics of Pachygrapsus marmoratus in the southern Black Sea (Turkey). Journal of the Marine Biological Association of the United Kingdom, 94, 1441-1449. DOI: $10.1017 /$ S0025315414000253.

Aydın, M. \& Sözer, A. (2019). The Length-weight relationship and condition factor of striped sea bream Lithognathus mormyrus (L., 1758) in the southern Black Sea Region. Journal of Anatolian Environmental and Animal Sciences. DOI: 10.35229/jaes.565282.

Bayed, A. \& Guillou, J. (1985). Contribution à 1 ètude des populations du genre Donax: la population de $D$. trunculus L. (Mollusca, Bivalvia) de Mehdia (Maroc), Annales de I'Institut Ocèanographique, 61(2), 139-147.

Bayed, A. (1990). Reproduction de Donax trunculus sur la cote Atlantique marocaine. Cah Biol Mar, 31, 159-170.

Bayed, A. (1991.) Étude écologique des écosystèmes de plages de sable fin de la côte atlantique marocaine: Modèles de zonation, Biotypologie, Dynamique de populations. $\mathrm{PhD}$. Thesis. University of Mohammed V, Rabat. 229pp.

Bayed, A. (1998). Variabilité de la croissance de Donax trunculus sur le littoral marocain. CIHEAMOptions méditerranéennes, 35, 11-23.

Bodoy, A. (1982). Croissance saisonnière du bivalve Donax trunculus L. en Méditerranée nordoccidentale (France). Malacologia, 22(1-2), 353358.
BSGM, (2016). Fisheries statistics, Web:http://www.tarim.gov.tr/sgb/Belgeler/SagM enuVeriler/BSGM.pdf

Çolakoğlu, S. (2011). Çanakkale Boğazı ile Batı Marmara'da kum midyesi (Chamelea gallina, L., 1758) ve kum şırlaninin (Donax trunculus, L., 1758) stok tahmini. PhD thesis, Ege University, Institute of sciences, 120s. (In Turkish)

Çolakoğlu, S. \& Tokaç, A. (2011). Some population parameters of the wedge clam (Donax trunculus L., 1758) in the west Marmara Sea. EgeJFAS, 28(2), 65-70.

Çolakoğlu, S. (2014). Population structure, growth and production of the wedge clam Donax trunculus (Bivalvia, Donacidae) in the West Marmara Sea, Turkey. Turkish Journal of Fisheries and Aquatic Sciences, 14, 221-230. DOI: 10.4194/1303-2712v14_1_24.

Deval, M.C. (2009). Growth and reproduction of the wedge clam (Donax trunculus) in the Sea of Marmara, Turkey. Journal Applied Ichthyology, 25(5), 551-558. DOI: $10.1111 / \mathrm{j} .1439$ 0426.2009.01258.x.

Froese, R. (2006). Cube Law, Condition Factor and Weight-Length Relationships: History, MetaAnalysis and Recommendations. Journal Applied Ichthyology, 22(4), 241-253. DOI: 10.1111/j.1439-0426.2006.00805.x.

Gaspar, M.B., Ferreira, R. \& Monteiro, C.C. (1999). Growth and reproductive cycle of Donax trunculus L., (Mollusca: Bivalvia) off Faro, southern Portugal. Fish Res., 41(3), 309-316. DOI: 10.1016/S0165-7836(99)00017-X.

Gaspar, M.B., Chícharo, L.M., Vasconcelos, P., Garcia, A., Santos, A.R. \& Monteiro, C.C. (2002a). Depth segregation phenomenon in Donax trunculus (Bivalvia: Donacidae) populations of the Algarve coast (southern Portugal). Scientia Marina $\quad \mathbf{6 6}(2), \quad 111-121 . \quad$ DOI: 10.3989/scimar.2002.66n2111.

Gaspar, M.B., Santos, M.N., Vasconcelos, P. \& Monteiro, C.C. (2002b). Shell morphometric relationships of the most common bivalve species (Mollusca: Bivalvia) of the Algarve coast (southern Portugal). Hydrobiologia, 477, 73-80. DOI: 10.1023/A:1021009031717.

Gaspar, M.B., Santos, M.N., Leitão, F., Chícharo, L., Chícharo, A. \& Monteiro, C.C. (2003). Recovery of substrates and macro-benthos after fishing trials with a new Portuguese clam dredge. Journal of the Marine Biological Association of the United Kingdom 83, 713-717. DOI: $10.1017 /$ S0025315403007690h. 
Guillou, J. (1980). Les peuplements de sables fins $d u$ littoral nord-Gascogne. PhD. Thesis. University of Bretagne occidentale. 209 pp.

Guillou, J. \& Bayed, A. (1991). Contraintes du milieu sur les populations de Donax trunculus L. et Donax venestus Poli, du littoral atlantique marocain. Oceanol Acta 14(3), 291-298.

Hafsaoui, I., Draredja, B., Lasota, R., Como, S. \& Magni, P. (2016). Population dynamics and secondary production of Donax trunculus (Mollusca, Bivalvia) in the Gulf of Annaba (Northeast Algeria). Mediterranean Marine Science, 17(3), 738-750. DOI: 10.12681/mms. 1760 .

Huz, R., Lastra, M. \& López, J. (2002). The influence of sediment grain size on burrowing, growth and metabolism of Donax trunculus L. (Bivalvia: Donacidae). Journal of Sea Research, 47, 85-95. DOI: 10.1016/S1385-1101(02)00108-9.

Mazé, R. \& Laborda, A.J. (1988). Aspectos de la dinámica de población de Donax trunculus (Linnaeus, 1758) (Bivalvia: Donacidae) en la ría de el Barquero (Lugo, NO España). Investment Pesquera, 52, 299-312.

Mazé, R.A. \& Laborda, A.J. (1990). Cambios estacionales de una población de Donax trunculus (Linnaeus, 1758) (Pelecypoda: Donacidae) en la ría de El Barquero (Lugo, NO. De Espana). Scientia Marina, 54(2), 131-138.

Mouëza, M. (1972). Contribution a l'étude de la biologie de Donax trunculus L. (Mollusque, Lamellibranche), dans l'Algérois: écologie en baie de Bou-Ismael. Tethys, 4, 745-756.

Moueza, M. \& Frenkiel-Renault, L. (1973). Contribution a l'ttude de la biologie de Donax frunculus L. (Mollusques:Lamellibranches) dans 1'Algerois: la reproduction. Cahiers de Biologie Marine, 14, 261-283.

Mouëza, M. \& Chessel, D. (1976). Contribution à l'étude de la biologie de Donax trunculus L. (Mollusque Lamellibranche) dans l'Algérois: analyse statistique de la dispersion le long d'une plage en baie de Bou-lsmail. Journal of Experiment at Marine Biology and Ecology, 21, 211-221. DOI: 10.1016/0022-0981(76)90116-7.

Neuberger-Cywiak, L., Achituv, Y. \& Mizrahi, L. (1990). The ecology of Donax trunculus Linnaeus and Donax semistriatus Poli from the Mediterranean coast of Israel. Journal of Experiment at Marine Biology and Ecology, 134(3), 203-220. DOI: 10.1016/00220981(89)90070-1.
Özden, Ö., Erkan, N. \& Ulusoy, S. (2009). Seasonal variations in the macronutrient mineral and proximate composition of two clams (Chamelea gallina and Donax trunculus). Journal International Journal of Food Sciences and Nutrition, $\quad 60(5), \quad 402-12 . \quad$ DOI: 10.1080/09637480701772945.

Öztürk, B, Doğan, A, Bakır, B.B. \& Salman, A. (2014). Marine molluscs of the Turkish coasts: an updated checklist. Turkish Journal Zoology, 38(6), 832879. DOI: 10.3906/zoo-1405-78.

Parsons, T.R., Takahashi, M. \& Hargrave, B. (1990). Biological oceanographic processes. Third edition, Pergamon press, Great Britain, 330p.

Ricker, W.E. (1975). Computation and interpretation of biological statistics of fish populations. Journal of the Fisheries Research Board of Canada, 191, 382.

Tirado, C. \& Salas, C. (1998). Reproduction and fecundity of Donax trunculus L. 1758 (bivalvia: Donacidae) in the littoral of Malaga (Southern Spain). Journal of Shellfish Research, 17, 169176.

Tunca, E., Aydın, M. \& Şahin, Ü.A. (2016). Interactions and accumulation differences of metal(loid)s in three sea cucumber species collected from the Northern Mediterranean Sea. Environmental Science and Pollution Research, 23, 2102021031. DOI: 10.1007/s11356-016-7288-7.

Yılmazer, N. (2005). Donax trunculus (Bivalvia: Donacidae) ovaryumunun morfolojisi ve oogenezinin ince yaplst. Istanbul University. Institute of sciences. $\mathrm{PhD}$ thesis. 116p (in Turkish).

Zeichen, M.M., Agnesi, S., Mariani, A., Maccaroni, A. \& Ardizzone, G.D. (2002). Biology and population dynamics of Donax trunculus L. (Bivalvia: Donacidae) in the South Adriatic Coast (Italy). Estuarine, Coastal and Shelf Science, 54, 971-982. DOI: 10.1006/ecss.2001.0868. 